\title{
Biomass, Man and Seasonality in the Tropics
}

\author{
Colin Leakey
}

\section{Introduction}

'Biomass' has become one of the modern clichés. Most things discussed beneath its shade were in existence long before the word was invented, and many have been forgotten. Nevertheless, considering the seasonality of biomass and its use by man, it creates a good frame of reference for addressing problems of the human condition in the tropics. I welcome the opportunity to contribute to the discussion.

I shall not attempt a rigid definition of biomass, for definitions can constrain thought, but will point out that by biomass I am referring to structured organic matter, living or dormant, and sometimes even dead, and comprised within the plant kingdom, the animal kingdom and micro-biological organisms. Biomass has become important in recent discussion, and particularly since the inauguration of the International Biological Programme (IBP), because its production, primarily through photosynthesis and thence by transformation in food chains, is a good measure of renewable resource potential.

The IBP was set up in 1964 to explore and define 'The Biological Basis of Productivity and Human Welfare' and because of the recognition then that the security of rapidly expanding human populations called for more rational management of natural resources.

The renewable energy potential (for heat or work) occupies the greatest part of the biomass literature [Montalembert 1983], but since biomass potential also provides limits to food production potential (in spite of this potential rarely being reached or even approximated) the biomass concept provides a frame of reference for considering the competing demands for food and fuel energy.

\section{Annual Versus Seasonal Data Sets}

Most are aware of some advantages of data compression, but compression of seasonal data to

1 I wish to acknowledge the assistance of Susan Leakey. annual data in relation to crop production has long been recognised as unfruitful, though it is surprising how often one sees annual data uncritically tabulated or quoted.

Much environmental data of significance to man's ecology is quoted in the form of monthly means, and such figures for many parameters are quite useful. The production of new biomass through photosynthesis depends of course on a concurrence of suitable temperatures, and, on occasion, the duration per day of solar radiation, which varies seasonally to a greater extent the further one departs from the equator, and on soil moisture. The latter depends on rainfall and loss of water from the root zone. The root zone in turn depends upon the depth of rooting which different species are able to exploit.

\section{Photoperiod and Seasonality}

The adaptation of many indigenous plants that reproduce by seed involves a precise timing of seed production and dispersal which maximises the chance of satisfactory re-establishment in the succeeding season. This is largely achieved by what is called photoperiodism. The length of dark period (night length) determines when flowering, and hence seeding, occurs. Under natural selection, genes or gene combinations determining that precise photoperiodic adaptation are selected in each latitudinally adapted sub-population of species. Frequently, under man's selection in research stations or under less sophisticated selection, it has been considered advantageous to eliminate photoperiod sensitivity and to develop strains that can be sown and cropped under wider latitude conditions. It is implied in this selection that agricultural practices will make less necessary the naturally selected adaptations for survival. It has to be questioned, when satisfactory agricultural husbandry conditions can not in fact be met, whether dismantling naturally evolved mechanisms of adaptation are as beneficial as has sometimes been supposed.

IDS Bul/etin. 1986, vol 17 no 3, Institute of Development Studies. Sussex 


\section{Moisture Regime and Seasonality}

Mean seasonal data, unless used critically, may obscure the biologically very important variation of reliability/unreliability of rainfall at particular times of the year. Manning $(1950,1955)$ was probably the first to point this out, and present an approach using confidence' limit parameters based on statistical analysis of year to year variation in rainfall in the same calendar periods. Other workers for the Cotton Corporation brought the analysis forward into the computer age [Walker and Rijks 1967] _- an important early example of the use of computers in agricultural support. The environmentalists at ICRISAT have made great strides in the analysis of rainfall reliability as well as seasonality in semi-arid areas, for example, in Niger [Sivakumar, Virmani and Reddy, undated].

The treatment of climate in the conference on seasonality held in 1978 [Walsh 1981], while good in some respects seems to me to step backwards by not commenting on the overriding effect of lack of reliability over climatic characterisation based on seasonal means. A seasonal classification based on monthly means, and through these an analysis of the numbers of wet and dry months (averaged across years) is likely to be a much better predictor of potential useful biomass production when applied to deep rooted plants (such as most natural climax vegetation) than to shallow rooted ones often resulting from the deflected successions, far removed from climax, which result from man's activities in the environment. (As I sit writing this in my study I am looking at an Australian calendar with a photograph of a magnificent, totally green gum tree in a landscape where there are no living shallow rooted annuals.) Once man becomes a significant part of the ecosystem he himself must develop flexible strategies to cope with the increased unreliability of biomass potential production which he produces if he is to survive. It could be claimed (although this is a somewhat broad generalisation) that by encouraging agriculture based on shallow rooted crops typical of temperate agriculture, those who intended to assist in the development of food security have used a strategy which is likely to do just the reverse.

\section{Plant Life-forms and Seasonality}

The concept of the diversity of life-form in higher plants as a basis of adaptation to climatic seasonality has a long history in classical botany. One of the most famous names is that of Raunkiaer, who in 1910 distinguished groups of plants according to the modes of protection and size of the meristem (buds) which would enable them to make the most effective use of the conditions of moisture and temperature allowing growth to occur. This is not the place to review
Raunkiaer's life forms in detail, but he envisaged a different 'biological spectrum' of plant life forms characteristic of and adapted to different climates [Skene 1924]. The discussion of life-form in relation to seasonal production of biomass that man might use for his welfare is something which nutritionists and agronomists may wish to revive.

\section{Geophytes}

Geophytes, in Raunkiaer's classification, comprised that group of plants whose perennial 'life form' allows for seasonal protection of the vegetative meristem from which growth will be resumed to be in an underground position - for example, in an organ such as a bulb or tuber. The protection of vegetative buds as an aspect of classification of plant types is interesting also in relation to biotic pressures on biomass. Although it may not have been stated in such terms, the recognition of the value of cassava as a famine reserve crop in Africa during the colonial agricultural period depended upon the combined value of unpalatability of the parts of the plant above ground to locusts, and there being a high proportion of the plant biomass underground where it was in any case protected from predators.

Within the framework of 'modernised agriculture' there has been all too little work on the development of new food resources based on combinations of biological, as opposed to technological, factors of storability. This reflects a continuing concept that modern agriculture ought to be made labour-saving, technologically efficient and increasingly capital intensive. Root crops, through lack of sufficient attention by plant breeders have not lent themselves to mechanised modernisation. While the potato in temperate countries has received sufficient attention for it to be treated as a large-scale mechanised farm crop, it is still severely limited to cultivation on a small range of soil types. Efforts in the tropics to turn cassava into a simply mechanised crop have been recognised as a worth-while research goal by only a select few, and the resources allocated to this task have not been great.

In much of tropical Africa there is no clear distinction, even under favourable climatic conditions, between agriculture and gathering of indigenous plants for foods as contributions to regular food supply [Tallantire and Goode 1975; Jerome et al. 1980]. In some desert and semi-desert areas, staple food is regularly harvested from naturally occurring geophytes [Malan and Owen-Smith 1975], just as was apparently the practice in earlier times in the south western USA [Nabhan and Felger 1980].

Unimproved and neglected wild plants that continue to provide famine reserve food from their underground 
storage organs, for those with the knowledge and skills to find them, are not even discussed in most academic agricultural training - or only to a minimal extent [Irvine 1952]. There are many such plants awaiting study.

Most of the swollen rooted and tuberous species, which can potentially sustain man by their stored reserves in seasons unfavourable for above-ground food production, contain toxins.

As with cassava, it is probable that many of the geophytes could be selected or bred for low levels of toxicity. This could well deprive them of their ability to resist predation by man's competitors in the ecosystem. Man's intelligence has allowed him, rather than his competitors in the food system, to use otherwise toxic plants in times of famine by learning how to de-toxify them. This is an important alternative strategy to that of breeding or selecting 'sweet' versions of the species concerned, and is an aspect of the chemurgic ${ }^{2}$ approach to food suggested by Pirie (1962). Of the geophytes, a substantial list of species of many genera and families are known to be used, or have been used, successfully as man's food. Many of these grow in harsh climatic conditions of highly unreliable as well as seasonal rainfall. The geophyte habit is an adaptation to the unreliability of primary production, of which primitive man long ago recognised the value to himself. Could not modern man do the same?

\section{Phanerophytes}

Phanerophytes are the life-form of perennial species which include trees and shrubs in which the buds (meristem) which remain dormant as a means of surviving the non-growing season are carried well above ground. People continue to use a much greater number of trees than geophyte species for food, though most of the trees that are used today provide sweet pulpy fruits of one sort or another, or nuts and oil-bearing seeds. The hiving-off of phanerophytes from mainstream agriculture, either into pomological horticulture or into silviculture, can be seen in retrospect to have been a disservice to research support for man's food resources. Even the modern invention of the term 'agro-forestry' [King and Chandler 1978] which may yet provide a theatre for a tree food strategy has, until now, failed to achieve much more than encouraging foresters to think about the relationship between their trees and the agriculturalist's crops.

\footnotetext{
${ }^{2}$ Chemurgy implies finding ways to make effective use of what grows naturally as an alternative to manipulating the environment by agricultural technology in order to grow desired species that would not thrive naturally.
}

The benefits of phanerophytes in 'agricultural' systems have been most apparent in equatorial rainfall areas, where the problem of superceding indigenous perennial crop-based systems with mechanised therophytic agriculture have been those of access to the land by machinery and the problems of soil management, including erosion. Regrettably, it has been far easier to till the land made available by destroying trees in semi-arid environments with highly unreliable rainfall. The use made by unschooled indigenous people in such environments of trees for food is only just beginning to be appreciated, and the productivity of such systems measured.

The publication of the proceedings of the arid lands conference at Kew (KICEPAL - Kew International Conference on Economic Plants in Arid Lands [see Wickens et al. 1984] may prove a turning point in economists' and planners' perceptions of the future role of tree crops far beyond the plantation agricultural concepts of the equatorial tropics. If, as examples, one were to pick only a handful of important resource species whose role had been neglected, it would include Parkia biglobosa, the African locust bean, which provides a weaning food from the orange-coloured pulp of the seed pod, and a widely used and nutritious condiment from its fermented seed; Adansonia digitata, the baobab, of which the white pulp around the seeds of the large fruits is an important starchy food for many; Phoenix dactilifera, the date palm which is cultivated far beyond is traditional range by the use of suitable genotypes; and Ficus sycamorus, the tree fig. There are many other food trees however, equally deserving of greater attention. Some of these phanerophytes, moreover, have advantages of what superficially might be considered perverse phenology. Such trees and shrubs expand their tender, fresh flushes of leaves during the dry season and drop their old leaves during the wet season. Perhaps the most famous of these is Acacia albida, which, on account of this, can provide both useful browse for cattle in the dry season and plenty of light beneath its canopy in the wet season to allow the growth of therophytic crops. It is unfortunate that this much-favoured tree species has seeds which, although superficially palatable, are also potentially dangerously toxic to man since they contain the same unusual free amino acid as Lathyrus sativus [Qureshi et al. 1977].

A second example of an important food shrub with new leaves developing in the dry season in West Africa is Moringa pterygosperma (the ben tree) which is very widely grown around the edge of house compounds, and whose leaves provide one of the most important dry season pot herbs. Better known than the human food trees, but I believe insufficiently appreciated, are the forage trees such as Daniella oliveri, whose leaf 
production in the dry season provides most of the dry season feed for the cattle of the Fulani. The extent to which this is overlooked can be judged from the fact that Sandford's recent book makes no mention whatever, in a chapter on the use of trees as livestock food [Sandford 1983].

\section{Therophytes, including Ephemerals}

Therophytes comprise those plants in which the dormant bud is enclosed within seeds as a means of surviving the non-growing season. Many traditional edible seed producing species are largely overlooked in agricultural project planning, but some may have great potential in marginal areas [Dendy, Emmett and Oke 1975]. Within this life form can be distinguished 'ephemerals', species with extremely rapid life-cycles which are able to germinate from seed and pass through a complete life-cycle to the production of new seed on the minimum amount of water, and in the shortest time. Hardly surprisingly, such species do not figure in lists of useful crop plants where yields are measured in quantity per unit area regardless of the length of the growing period (as mustard and cress is not compared with alfalfa as a forage crop!). There has been an interest since the emergence of the biomass concept, and the International Biological Programme is taking more interest in yield as a function of duration of life cycle as well as area, but this does not seem to have moved far enough to considering the potential role of highly ephemeral species as crops.

Even with the widening of the number of species of 'millet' now being studied by ICRISAT, I understand [Willey 1985 personal communication] that no serious attention is being given to the one or more (depending on your taxonomic viewpoint) species of Digitaria (Digitaria exilis, etc.) sometimes called 'hungry millet' in West Africa. Yet the importance of this millet in those communities where it is regularly grown is rated very high. On the contrary, agricultural research emphasising yield per unit area must, if anything, have tended to favour selection of cultivars of crop species requiring longer periods of moisture availability. In eastern and south-central Africa, specifically in southern Tanzania, northern Zambia and northern Malawi, the farmers themselves have conserved and continue to grow ultra-early maturing varieties of both finger millet, which is an indigenous crop, and maize. Where maize is concerned, genetic resources of the early introductions by the Portuguese are in many areas much better adapted than the white, semi-dense varieties introduced from South Africa by the missionaries early in the 19 th century. Governments usually want to 'flush' these out with new varieties.

\section{The Uses of Plants by Man}

The potential conflicts between biomass use for food and biomass use for energy are widely discussed. Less fashionable is the use of plant resources for drugs in the wide sense, including the local medicine man's pharmacopoeia and the widespread use of simple stimulants. These have important seasonal aspects.

\section{Pharmacognosy}

Knowledge about the medicinal properties of plants and how to recognise them is what is covered by this scientific subject area, that is of rapidly renewing interest [Trease and Evans 1978]. Until about 50 years ago, collections from wild plants, or occasionally from species specially cultivated, provided a large proportion of the world's medicine. The synthetic chemical industry and, more recently, micro-biological contribution to the pharmaceutical industry have both had potentially adverse effects on the rural economy of man. This arises from what is taught by those from the towns, and increasingly accepted as true by rural people, that medicinal contributions to health arise from the urban sector. Whether they are paid for, or provided free, may make a financial difference, but in either case the change serves to make rural living more dependent on urban industry. The early years of this century saw most 'native medicine' discounted as little more than quackery, but the emergence of some recent drugs, such as reserpine from Rauwolfia serpentina through the proper investigation of this long-standing Indian native medicine, and other similar developments, has done much to re-establish the credentials of traditional medicines. Sub-Saharan Africa has probably had far less attention devoted to its indigenous plants and their uses than most of South Asia, South East Asia and Latin America [Miller 1980].

Five substantial volumes of great detail about Sri Lankan medicinal plants are a tribute to the wealth of economic resources that are often overlooked and that compilation of information provides a very commendable model [Jayaweera 1981-3]. There are some important local economic collecting activities involving the uncontrolled exploitation of unmanaged resources, but so far in sub-Saharan Africa there have been few systematic attempts to study and develop local resources for medicinal use. ${ }^{3}$ A start was made in Uganda, from about 1965-70, with the Natural Chemotherapeutics Research Unit (with which I was pleased to have a marginal involvement). In Senegal, [Schissel 1984] a parallel attempt was made to that in Uganda, but with half-hearted minimal support. Local area studies of indigenous medicines have appeared [Lindsay and Hepper 1978; Oliver 1960] and there is a network being established under the auspices of the Ethiopian Pharmaceutical Association [NAPRECA 1984] with the intention of trying to

\footnotetext{
Since this was written Medicinal Plants in Tropical Africa (1986) by
} Bep Oliver-Bever has been published. 
stimulate appropriate research and development work, but there is still little evidence of any widespread understanding among planners of the benefits that could arise from such activity, still less the potential scale of economic benefit by liberating sub-Saharan Africa to a substantial extent from dependence on the drugs industry of the North.

Even where economic activity is still recognised in the collection of wild plant products, such as the Sudan where the collection of gum Arabic is the second largest foreign exchange earner in the country, this industry and its product can be threatened when it becomes convenient to the North to do so, both by regulatory restrictions and the threat of synthetic substitutes. If southern Africa could set its sights on training its chemists and developing its chemical and pharmaceutical industry to use indigenous resources effectively, they would provide useful openings for the seasonal economic exploitation of neglected biomass.

\section{Stimulants}

The well-fed North, adequately and often overnourished throughout the year, regards year-round adequacy of nutrition as the obvious goal of nutritional planning. However, seasonal constancy in diet and plane of nutrition should be regarded as very much the abnormal situation in relation to man's place in time and space in the world eco-system. Much more normal is a food calendar with periods of ample nutrition separated by periods of malnutrition. The biomass of the human population itself, as well as that of game animals and domestic livestock, has a natural periodicity. As an extension of this view, but one into which I will not digress, would be the suggestion that high infant and adult mortality as a periodic phenomenon is also historically the norm. In almost every society where there are substantial seasonal changes in food availability, the use of appetite suppressants, which divorce hunger from malnutrition and allow hard work to be carried out while burning reserves, has been commonplace. This has been an alternative strategy, though sometimes carried out parallel with food storage, to avoid the limitation of nutritional seasonality.

Large numbers of plants are used around the world in this way, but among the four best known which will serve as examples here are betel nut from the Areca palm throughout south-east Asia; khat, the chewed leaves of Catha edulis [NAPRECA 1984] in Arabia and coastal eastern and central Africa; coca, the leaves of Erythroxylon supp. in the Andes, and Kola in West Africa. Coca-Cola presumably recognised the value of these last two species in its original formulation. The beverage plants that we have taken into northern culture are from the same group of natural stimulants.
Cocoa and coffee were both used indigenously by sucking or chewing the pulp around the ripe seeds as a much simpler source of 'pep' before their alkaloids were used and extracted in a more marketable and now well-known form. Whatever the undesirable sideeffects of concentrated extracts from any of these traditionally exploited biomass species may be, it ought to be recognised that the use of plants by man to allow himself to adapt to the rigours of seasonal and uncertain food supplies, is deeply culturally embedded in our species.

\section{Natural Resource Choices and Economic Paradigms}

Real investors who spend their own money, and even those surrogates, the planners, who decide on the spending of other's money, are, as we all understand, concerned for the quick buck. The net present value of benefits must exceed the net present value of costs if there is to be a high rate of return. I would need longer to argue the point, but will now assert that to plan for short-term benefit automatically biases planning against long-term benefit. When Keynes said that in the long-run we are all dead' he had not thought about the evolutionary philosophy of 'the selfish gene'. More people recently have begun to consider the world which their descendants will inherit, and to realise that those who inhabit the earth today, even though soon dead, have a moral obligation to the future. This should lead us towards a new development philosophy based on the net future, rather than net present benefits, which might have startling consequences for decision-making.

For example, anyone who has had the experience of suggesting that from a resource point of view it might be interesting to encourage the planting of trees as a contribution to development, whatever economic product may be in view, will have met the objection, of ten insurmountable, of the relatively long time-lapse before benefits begin to accrue. Anyone working on lesser-known crops will have met objections that to give attention to them instead of to crops in which there is a strong research background is not feasible. Both these views should be questioned and challenged if we are to make an effective change of direction from a development path which has not demonstrably improved the human condition in sub-Saharan Africa.

\section{Population Control in a Seasonal Environment}

Dyson and Crook, in a very interesting contribution to the 1978 conference [Chambers et al. 1981] drew attention to the considerable degree of seasonality in births and deaths. Their study did not, however, take account of the probably substantial use made of plant products for contraception, and even more 
importantly, for securing abortion [see Fig. 5.1, page 136]. Most studies on ethnobotany or 'native medicines' include specific reference to large numbers of species used for controlling fertility. Perhaps there should be more sociological studies to identify the circumstances and frequency with which such plants are used, particularly whether their use is now diminishing with the increasing movement away from traditional cultural practices. Kokwaro (1976) for example, lists no less than 28 species used in East Africa for securing abortion. The distinction between abortifacients and contraceptives is a subtle one that need not detain us here. What is clear is that artificial intervention to modify the birth-rate is a long-standing practice. It would be interesting, in time, to learn whether man has had a long history, hitherto overlooked, of attempting to match population to carrying capacity.

\section{Conclusions and Suggestions}

Of all the world species, man is perhaps the one who has evolved to occupy the largest number of niches. It is reasonable to assume that this success in colonisation has been a result of his intelligence, which both enables him to adapt to the food supplies that are available, and only later to develop the distribution of food supplies between niches, so as to exceed the carrying capacity of each. Man's ability to respond to climatic seasonality within any broad geographical area will have included migrations to follow the availability of food which survives in nomadism, periodic fluctuations. in population in response to food resource and disease, which continues in the disasters of today, but perhaps above all, in the extraordinary range of food species which he has learnt to use. At the present time nomadism is increasingly unacceptable to politicians, with forced migration, curiously, being regarded occasionally as a political necessity which may be far less humane. Massive natural fluctuations in population becomes increasingly unacceptable too as modern communications media lead to its extent being understood, by those areas where carrying capacity is more stable, while at the same time we create the means of extinguishing a large part of the human race. The third historical factor of food diversity we can, and should, encourage. Agricultural research should be much more concerned to widen the food base, in particular by making use of a greater range of plant life forms as food resources.

If is encouraging that in the Third Lomé Convention signed recently (see The Courier, ${ }^{4}$ January 1985) article 42 of the Convention is devoted to recommendations that are broadly in line with those suggested by this article.

\footnotetext{
${ }^{4}$ An official monthly publication of the European Community. The January 1985 edition sets out the conclusions of the Third Lomé convention.
}

\section{Article 42}

If a return to the natural balance is to be expected, a 'drought and desertification control' component in particular must be incorporated into all agricultural and rural development operations, such as:

1. - extension of agro-forestry systems combining farming and forestry research and development activities to produce plant species that are more adapted to local conditions;

- the introduction of suitable techniques aimed at increasing and maintaining the productivity of agricultural land, arable land and natural pastureland with a view to controlling the various forms of erosion;

- the reclamation of land that has deteriorated, by means of reafforestation or agricultural land improvement, combined with maintenance schemes involving, as far as possible, the people and authorities concerned in order to safeguard the progress made;

2. - the encouragement of measures to economise on wood as an energy source by stepping up research, application of, and information on, new and renewable sources of energy such as wind, solar and biomass energy, and by the use of improved stoves with a greater heat yield;

3. - the development and management of forestry resources by setting up at national or regional level, forestry management plans aimed at optimising the exploitation of forestry resources;

4. - the pursuit of ongoing campaigns to educate the people concerned to be aware of the phenomena of drought and desertification and to train them in the possible ways of controlling them.

The purpose of this Bulletin is to identify and sharpen practical policy implications of the recognition of the inevitable continuation of climatic fluctuation, seasonal trend changes and massive unreliability, and to point to practical measures that might ameliorate their effect.

1. Within the general terms of Article 42 of Lomé 3, it is now suggested that, rather than agroforestry systems combining farming and forestry research' we should cease to make, as far as possible, the traditional distinction between agriculture and forestry. Specifically, we should put far more effort into the silviculture of food. 
2. We must recognise that the productivity of agricultural land, under low rainfall, depends very much more upon exploiting the diversity of lifeforms adapted over millions of years to the environment instead of basing so much of our planning of food production on seed crops from therophytes.

3. We should educate politicians and planners trained in one set of environmental circumstances to learn about and to understand more of the realities of the ways in which man has come, through evolution, to be able to live in other environments.

Going beyond the terms of Article 42, and more contentiously, I believe we should recognise that a low infant mortality and a low adult death rate detract from the flexibility which has enabled human population to survive in harsh areas through rapid changes and responses in population to meet changes in carrying capacity.

Very much greater attention should be given to traditional medicines and social plant products and the modernisation and potential improvement of their use, rather than allowing or encouraging greater dependency for health care on remote industry.

Finally, we should avoid setting our expectations of what can be achieved by intervention far beyond any reasonable possibility of success. As an alternative, we might pay more attention to trying to avoid interventions which have a high probability of making matters worse.

\section{References}

Chambers, R., R. Longhurst and A. Pacey (eds.), 198I, Seasonal Dimensions to Rural Poverty, Frances Pinter, London

Dendy, D. A. V., B. Emmett and O. L. Oke, 1975, 'Minor food seeds', in N. W. Pirie (ed.), Food Protein Sources, Cambridge University Press

Irvine, F. R., 1952, 'Supplementary and emergency food plants of West Africa', Economic Botany 6, pp23-40

Jayaweera, D. M. A., 1981-3, Medicinal Plants used in Ceylon (5 vols) National Science Council of Sri Lanka

Jerome, N. W., R. F. Kandel and G. H. Pelto, 1980, Nutritional Anthropology: Contemporary Approaches to Diet and Culture, Redgrave, New York

King, K. F. S. and M. T. Chandler, 1978, The Wasted Lands, The Programme of work of ICRAF, International Council for Research in Agroforestry, Nairobi

Kokwaro, J. O., 1976, Medicinal Plants of East Africa, East African Literature Bureau, Nairobi
Lindsay, R. S. and F. N. Hepper, 1978, Medicinal Plants of Marakwet, Kenya, Royal Botanic Gardens, Kew

Malan, J.S. and G. L. Owen-Smith, 1975, 'The Ethnobotany of Kaokoland', Cimbebasia, vol 2 no 5, ppl $31-78$

Manning, H. L., 1950, 'Confidence limits of expected monthly rainfall', Journal of Agricultural Science 50, pp 169-76

- 1955, 'The statistical assessment of rainfall probability and application in Uganda agriculture', Proceedings of the Royal Society Bulletin 144, pp460-80

Miller, J. A., 1980, 'Chemical fruits of the desert', Science News $118, \mathrm{p} 189$

Montalembert, M. R. de, 1983, 'Biomass resources of energy: the critical issues’, Ceres January-February, pp40-4

Nabhan, G. P. and R. S. Felger, 1980, 'Deceptive barrenness. The desert conceals food sources that prehistoric people knew how to exploit. Will modern man do as well?' SouthWest Bulletin (New Mexico Solar Energy Association) vol 5 no 4, pp 18-23 (Reprinted from Ceres, March-April 1976)

NAPRECA Newsletter (Natural Products Research Network for Eastern and Central Africa), 1984, Supplement to vol 1 Special Issue: Focus on the 'International Symposium on Chemical and Ethnopharmacological Aspects of Chat (Catha edulis)', 15 December, 1984, Addis Ababa

Oliver-Bever, B., 1960, Medicinal Plants in Nigeria, Nigerian College of Arts, Science and Technology

Pirie, N. W., 1962, 'Progress in biochemical engineering broadens our choice of crop plants', Economic Botany 15, p302

Qureshi, M. Y., D. J. Pilbeam, C. S. Evans and E. A. Bell, 1977, 'The Neurolathyrogen-amino-oxalylaminopropionic acid in legume seeds', Phytochemistry 16, p477

Sandford, S., 1983, Management of Pastoral Development in the Third World, Overseas Development Inst itute, London

Schissel, H., 1984, 'The missing ingredient headache', South, November, p99

Sivakumar, M. V. K., S. M. Virmani and S. J. Reddy (undated), Rainfall Climatology of West Africa: Niger, ICRISAT, Ouagadougou

Skene, M., 1924, The Biology of Flowering Plants, Sidgwick and Jackson, London

Tallantire, A. C. and P. M. Goode, 1975, 'A preliminary study of the food plants of the West Nile and Madi Districts of Uganda. The utilisation of leaves and fruits of local and mainly indigenous plants in supplementing the staple foods', East African Journal of Agriculture and Forestry, vol 40 no 3, pp233-55

Trease, G. E. and W. C. Evans, 1978, (1 lth ed.) Pharmacognosy, Bailliere Tindall, London 
Walker, J. T. and D. A. Rijks, 1967, 'A computer programme for the calculation of coinfidence limits of expected rainfall', Experimental Agriculture 3, pp337-41

Wickens, G. E., J. R. Goodin and D. A. Field, 1984, Plants for Arid Lands, George Allen \& Unwin, London
Walsh, R., 1981, 'The nature of climatic seasonality', in R. Chambers, R. Longhurst and A. Pacey (eds.), Seasonal Dimensions to Rural Poverty, Frances Pinter, London 